OPEN ACCESS

Edited by:

Pankaj Kumar Arora,

M. J. P. Rohilkhand University, India

Reviewed by:

Christopher Joseph Ennis,

Teesside University, UK

Kamaljeet K. Sekhon Randhawa,

Aalborg University Copenhagen,

Denmark

Angelina Lo Giudice,

National Research Council, Italy

*Correspondence:

Yahya M. Al-Wahaib

ymn@squ.edu.om

Specialty section:

This article was submitted to Microbiotechnology, Ecotoxicology and Bioremediation

a section of the journal

Frontiers in Microbiology

Received: 29 August 2016 Accepted: 03 November 2016 Published: 23 November 2016

Citation:

Joshi SJ, Al-Wahaibi YM,

Al-Bahry SN, Elshafie $A E$, Al-Bemani AS, Al-Bahri A and Al-Mandhari MS (2016) Production,

Characterization, and Application

of Bacillus licheniformis W16

Biosurfactant in Enhancing Oil

Recovery. Front. Microbiol. 7:1853.

doi: 10.3389/fmicb.2016.01853

\section{Production, Characterization, and Application of Bacillus licheniformis W16 Biosurfactant in Enhancing Oil Recovery}

\author{
Sanket J. Joshi', Yahya M. Al-Wahaibi ${ }^{2 *}$, Saif N. Al-Bahry ${ }^{3}$, Abdulkadir E. Elshafie ${ }^{3}$, \\ Ali S. Al-Bemani' ${ }^{2}$ Asma Al-Bahri' ${ }^{1}$ and Musallam S. Al-Mandhari ${ }^{4}$
}

${ }^{1}$ Central Analytical and Applied Research Unit, College of Science, Sultan Qaboos University, Muscat, Oman, ${ }^{2}$ Department of Petroleum and Chemical Engineering, College of Engineering, Sultan Qaboos University, Muscat, Oman, ${ }^{3}$ Department of Biology, College of Science, Sultan Qaboos University, Muscat, Oman, ${ }^{4}$ Petroleum Development Oman, Muscat, Oman

The biosurfactant production by Bacillus licheniformis W16 and evaluation of biosurfactant based enhanced oil recovery (EOR) using core-flood under reservoir conditions were investigated. Previously reported nine different production media were screened for biosurfactant production, and two were further optimized with different carbon sources (glucose, sucrose, starch, cane molasses, or date molasses), as well as the strain was screened for biosurfactant production during the growth in different media. The biosurfactant reduced the surface tension and interfacial tension to $24.33 \pm 0.57 \mathrm{mN} \mathrm{m}^{-1}$ and $2.47 \pm 0.32 \mathrm{mN} \mathrm{m}^{-1}$ respectively within $72 \mathrm{~h}$, at $40^{\circ} \mathrm{C}$, and also altered the wettability of a hydrophobic surface by changing the contact angle from $55.67 \pm 1.6$ to $19.54^{\circ} \pm 0.96^{\circ}$. The critical micelle dilution values of $4 \mathrm{X}$ were observed. The biosurfactants were characterized by different analytical techniques and identified as lipopeptide, similar to lichenysin-A. The biosurfactant was stable over wide range of extreme environmental conditions. The core flood experiments showed that the biosurfactant was able to enhance the oil recovery by $24-26 \%$ over residual oil saturation ( $\mathrm{S}_{\mathrm{or}}$ ). The results highlight the potential application of lipopeptide biosurfactant in wettability alteration and microbial EOR processes.

Keywords: Bacillus licheniformis, surface tension, interfacial tension, lichenysin, wettability alteration, core flood, microbial enhanced oil recovery

\section{INTRODUCTION}

Recent updates in our understanding of the microbial metabolisms and their biochemical pathways lead to different applications in petroleum industries like enhancing oil recovery, biodegradation of oil-based waste, treatment of oil-field produced water, bioremediation of oil-spills, etc. At present the worldwide crude oil market is quite volatile with fluctuations in prices. Still, there is an urgent need for new, efficient and superior oil recovery technologies, known as enhanced oil recovery (EOR) techniques. Amongst several types of EOR technologies, microbial enhanced oil recovery (MEOR) is considered to be quite promising one, environmental friendly greentechnology (Belyaev et al., 2004; Sen, 2008; Al-Sulaimani et al., 2011b; Zahner et al., 2011). 
Chemical surfactants and polymers are amongst highly utilized compounds in petroleum industries during EOR applications, for reducing surface tension (ST), interfacial tension (IFT), for generating oil-in water OR water-in-oil emulsions, heavy oil recovery by acting as a viscosifying agent, etc. However, recently the trend has been shifted toward applications of green-compounds or bio-products, mainly because of the environmental concerns. Biosurfactants are such biologically produced surfactants by microorganisms, plants, and animals. Biosurfactants are reported for reducing ST and IFT between oil/ water/rock interface, altering the rock wettability, initiating oil/water emulsions, or changing the hydrophilic-lipophilic balance (HLB), thus enhancing the oil recovery (Desai and Banat, 1997; Sen, 2008; Banat et al., 2010). Biosurfactants have been the focus of extensive research because of several advantages over chemical surfactants: considerably lower toxicity, better biodegradability and synthesis from cheaper-agro-industrial waste or renewable raw materials (Marchant and Banat, 2012a,b). Several companies around the globe (UK, USA, Japan, Germany, China) are producing different types of biosurfactant (such as rhamnolipids, lipopeptides, sophorolipids, etc.), with focus on different applications (such as pharmaceuticals, cosmetics, antimicrobials and anticancer, bioremediation, EOR, etc.) (Sekon and Rahman, 2014). Even with all these new developments and increased interest by prominent business-houses, the economically availability and wide-spread applications of biosurfactants are still limited in petroleum industries. The major reason is the availability of comparatively cheaper chemical surfactants and higher cost of biosurfactant production. Several researchers have reported different ways to tackle higher production costs by applying statistical optimization methods or by use of cheaper agro-industrial waste products (Sen and Swaminathan, 2004; Joshi et al., 2007, 2008a; Makkar et al., 2011; Al-Bahry et al., 2013; Saimmai et al., 2013; Chooklin et al., 2014). Different types of biosurfactants are reported, amongst which lipopeptide type of biosurfactant produced by Bacillus group are widely studied. Surfactins and lichenysins produced by Bacillus subtilis and Bacillus licheniformis strains are reported for their high surface activities and other beneficial properties suitable for several applications like enhancing oil recovery (Jean-Marc et al., 2003).

Sultanate of Oman is oil producing Middle Eastern country, where various EOR technologies are employed to enhance the crude oil recovery from the declining reservoirs in the sultanate. To check the potential of biosurfactant based MEOR applications in Oman, we isolated and screened several spore forming bacteria and analyzed for biosurfactant production (AlSulaimani et al., 2011a). Amongst several isolates, B. licheniformis W16 showed biosurfactant production and was further selected. The biosurfactant production by this isolate was studied in nine different reported minimal media, and five different carbohydrates were tested to find suitable carbon source in selected better media. The biosurfactant was studied further for wettability alteration (contact angle determination), critical micelle dilution (CMD), extracted and characterized, stability under harsh conditions and MEOR studies by core-flood using Berea sandstone core-plugs under reservoir conditions.

\section{MATERIALS AND METHODS}

\section{Chemicals and Reagents}

All chemicals, reagents and hydrocarbon ( $n$-heptane and $n$-hexadecane) were Analytical Reagent (AR) grade or HPLC grade, purchased from Sigma-Aldrich, Co., USA. Cane molasses and date molasses were purchased from the local market, Oman. Formation water and light crude oil was kindly provided by Petroleum Development Oman (PDO), Oman.

\section{Microorganism}

Previously reported bacterial isolate B. licheniformis W16 (GenBank Accession number GU945226), isolated from soil near an Omani oil well (Al-Sulaimani et al., 2011a) was used for all experiments. The isolate was maintained aerobically on LuriaBartani (LB) agar plates and was regularly transferred into fresh LB medium for short-term storage. Stock cultures of pure isolate were prepared in $40 \%$ glycerol and stored below $-80^{\circ} \mathrm{C}$, for long-term preservation.

\section{Screening of Biosurfactant Production Media}

For biosurfactant production studies, LB broth was used as a seed medium. After $15 \mathrm{~h}$ incubation at $40^{\circ} \mathrm{C}\left(\mathrm{OD}_{660 \mathrm{~nm}^{-}}\right.$ $1.0), 2 \%(\mathrm{v} / \mathrm{v})$ seed culture was transferred to $50 \mathrm{ml}$ each of different minimal production media in $250 \mathrm{ml}$ Erlenmeyer flasks. For initial screening, seven different minimal media and two media based on only molasses, for biosurfactant production were used for current studies, as reported by $\mathrm{Al}$ Sulaimani et al. (2011a). The compositions of minimal media (M) tested with different carbohydrates as a carbon sources are as follows ( $\mathrm{g}$ per $1000 \mathrm{ml}$ distilled water): M1 (Joshi et al., 2008b) - Glucose, 34; $\mathrm{NH}_{4} \mathrm{NO}_{3}, 1.0 ; \mathrm{KH}_{2} \mathrm{PO}_{4}, 6.0 ; \mathrm{Na}_{2} \mathrm{HPO}_{4}$, $2.7 ; \mathrm{MgSO}_{4} .7 \mathrm{H}_{2} \mathrm{O}, 0.1 ; \mathrm{FeSO}_{4} .7 \mathrm{H}_{2} \mathrm{O}, 0.00165 ; \mathrm{MnSO}_{4} .4 \mathrm{H}_{2} \mathrm{O}$, 0.001; $\mathrm{CaCl}_{2}, 0.0012 ; \mathrm{Na}_{2}$-EDTA, 0.000745. M2 (Joshi et al., 2007) - Glucose, 11.0; $\mathrm{NaNO}_{3}, 4.4 ; \mathrm{MgSO}_{4} .7 \mathrm{H}_{2} \mathrm{O}, 0.8 ; \mathrm{KCl}$, $0.4 ; \mathrm{CaCl}_{2}, 0.27 ; \mathrm{H}_{3} \mathrm{PO}_{4}(85.4 \%), 1.0 \mathrm{ml}$; Trace elements, $10 \mathrm{ml} \mathrm{l}^{-1}$. M3A (Joshi et al., 2008a) - Cane molasses, 80.0. M3B - Date molasses, 80.0. M4 (Landy et al., 1948) - Glucose, 20.0; Sodium glutamate, 5.0; $\mathrm{KH}_{2} \mathrm{PO}_{4}, 1.0 ; \mathrm{MgSO}_{4} .7 \mathrm{H}_{2} \mathrm{O}, 0.5$; $\mathrm{FeSO}_{4} .7 \mathrm{H}_{2} \mathrm{O}, 0.15 ; \mathrm{MnSO}_{4} .4 \mathrm{H}_{2} \mathrm{O}, 0.005 ; \mathrm{CuSO}_{4}, 0.16$; Yeast Extract, 1.0. M5 (Jenny et al., 1991) - Glucose, 20.0; $\mathrm{NaNO}_{3}$, 4.0; $\mathrm{MgSO}_{4} .7 \mathrm{H}_{2} \mathrm{O}, 0.4 ; \mathrm{Na}_{2}$-EDTA, 0.2; $\mathrm{H}_{3} \mathrm{PO}_{4}$ (85.4\%), $0.5 \mathrm{ml}$; Trace elements, $1 \mathrm{ml} \mathrm{l}^{-1}$. M6 (Youssef et al., 2007) Sucrose, $10.0 ; \mathrm{K}_{2} \mathrm{HPO}_{4}, 13.9 ; \mathrm{KH}_{2} \mathrm{PO}_{4}, 2.7 ; \mathrm{MgSO}_{4} .7 \mathrm{H}_{2} \mathrm{O}$, 0.25; Yeast Extract, $1.0 ; \mathrm{NaCl}, 50.0 ;\left(\mathrm{NH}_{4}\right)_{2} \mathrm{SO}_{4}$, 1.0; Trace elements, $10 \mathrm{ml} \mathrm{l}^{-1}$. M7 (Cooper et al., 1981) - Glucose, 20.0; $\mathrm{NH}_{4} \mathrm{NO}_{3}, 4.0 ; \mathrm{KH}_{2} \mathrm{PO}_{4}, 4.08 ; \mathrm{Na}_{2} \mathrm{HPO}_{4}, 7.12 ; \mathrm{MgSO}_{4} .7 \mathrm{H}_{2} \mathrm{O}, 0.2$; $\mathrm{FeSO}_{4} .7 \mathrm{H}_{2} \mathrm{O}, 0.0011 ; \mathrm{MnSO}_{4} .4 \mathrm{H}_{2} \mathrm{O}, 0.00067 ; \mathrm{CaCl}_{2}, 0.00077$; $\mathrm{Na}_{2}$-EDTA, 0.00148. M8 (Mukherjee et al., 2009a) - Sucrose, $20.0 ; \mathrm{NH}_{4} \mathrm{NO}_{3}, 3.3 ; \mathrm{K}_{2} \mathrm{HPO}_{4}, 2.2 ; \mathrm{KH}_{2} \mathrm{PO}_{4}, 0.14 ; \mathrm{MgSO}_{4} .7 \mathrm{H}_{2} \mathrm{O}$, $0.6 ; \mathrm{FeSO}_{4} .7 \mathrm{H}_{2} \mathrm{O}, 0.2 ; \mathrm{CaCl}_{2}, 0.04 ; \mathrm{NaCl}, 0.01$; Trace elements, $0.5 \mathrm{ml} \mathrm{l}^{-1}$. The flasks were incubated in a temperature controlled incubator shaker at $40^{\circ} \mathrm{C}, 160 \mathrm{rpm}$. The carbon sources were filter sterilized and added separately to minimal media after autoclaving. Samples were withdrawn at every $24 \mathrm{~h}$ 
interval and analyzed for $\mathrm{pH}$, growth $\left(\mathrm{OD}_{660}\right)$, biopolymer production (viscosity), and biosurfactant production -ST and IFT.

\section{Effect of Different Carbon Sources on Biosurfactant Production}

To check the effect of different carbon sources, five different carbohydrates were substituted to glucose and sucrose, in two selected minimal production media composition - M7 and M8. Seed medium (LB broth) was inoculated with loopful of bacteria and after $15 \mathrm{~h}$ incubation at $40^{\circ} \mathrm{C}\left(\mathrm{OD}_{660} \mathrm{~nm}^{-}\right.$ $1.0), 2 \%(\mathrm{v} / \mathrm{v})$ was transferred to production media - M7 and $\mathrm{M} 8(50 \mathrm{ml}$ in $250 \mathrm{ml}$ Erlenmeyer flasks) containing different carbohydrates (glucose, sucrose, starch, cane molasses, or date molasses) at $2 \%(\mathrm{w} / \mathrm{v})$ concentrations. The flasks were incubated in a temperature controlled incubator shaker at $40^{\circ} \mathrm{C}, 160 \mathrm{rpm}$ for up to $72 \mathrm{~h}$. The carbon sources were filter sterilized and added separately to minimal media after autoclaving. Samples were withdrawn at every $24 \mathrm{~h}$ interval and analyzed for growth $\left(\mathrm{OD}_{660}\right)$, and biosurfactant production - ST and IFT. All measurements were made on cell-free broth after centrifugation $(12,096 \times g$ for $20 \mathrm{~min})$ and analyzed at room temperatures. The experiments were performed in duplicate and the reported results are the mean of three independent experiments with standard deviation (SD) values.

\section{Biopolymer Analysis}

The samples were analyzed for biopolymer production using viscosity measurements at every $24 \mathrm{~h}$ interval up to $72 \mathrm{~h}$. One $\mathrm{ml}$ each of different cell-free samples was analyzed for any increase in viscosity using Quarzviskosimeter (QVis 01/L, Flucon, F5 Technologie, Germany) at room temperatures $\left(25 \pm 2.0^{\circ} \mathrm{C}\right)$.

\section{Biosurfactant Analysis, Contact Angle Measurements, and Critical Micelle Dilution (CMD) Measurements}

Biosurfactant production was analyzed by periodic measurements of any changes in surface activity - ST and IFT of cell-free samples by 'pendant drop method' using the Drop Shape Analyzing system - DSA 100 (KRÜSS, Germany). The IFT measurements were done against $n$-heptane or $n$-hexadecane. Contact angles of the abiotic controls (uninoculated media) and biosurfactants were measured using the Drop Shape Analysis System, DSA100 (KRÜSS, Germany), as reported by Al-Sulaimani et al. (2012). All measurements were done in triplicates at ambient temperature $\left(25 \pm 2.0^{\circ} \mathrm{C}\right)$ and atmospheric pressure $(1 \mathrm{~atm})$ and the average values were reported. The CMD was estimated by measuring the ST and IFT at varying dilutions of the sample (Joshi et al., 2008a).

\section{Biosurfactant Extraction and Characterization}

The biosurfactant was partially purified and extracted by the acid precipitation method (Youssef et al., 2005). Bacterial cells were separated by centrifuging at $12,096 \times g$ for $20 \mathrm{~min}$ at $20^{\circ} \mathrm{C}$ (Beckman, JLA 16.250 rotor, USA), and the $\mathrm{pH}$ of the cell-free broth was adjusted to 2.0 using $6 \mathrm{M} \mathrm{HCl}$. This acidified cell-free solution was incubated overnight at $4^{\circ} \mathrm{C}$, and the precipitated biosurfactant was collected by centrifuging the solution at $12,096 \times g$ for $25 \mathrm{~min}$ at $4^{\circ} \mathrm{C}$. The collected biosurfactant pellet was dissolved in $100 \mathrm{ml}$ distilled water, and its $\mathrm{pH}$ was adjusted to 8.0, with $1 \mathrm{~N} \mathrm{NaOH}$. Crude biosurfactant powder was collected by spray-drying reconstituted biosurfactant solution using Mini-Spray Dryer B-290 (BÜCHI, Switzerland), at set temperature program ranging between 100 and $160^{\circ} \mathrm{C}$. Extracted crude biosurfactant was then tested for its stability under different conditions, chemical characterization and in core-flooding experiments.

\section{Fourier Transform Infrared Spectroscopy (FTIR)}

The structural groups of the biosurfactant were partially identified using Fourier transform infrared spectroscopy (FTIR). Infrared (IR) absorption spectra were obtained with a PerkinElmer grating 1000 IR (Norwalk, CT, USA) in a dry atmosphere at Sultan Qaboos University, Oman. For analysis, $1 \mathrm{mg}$ of crude biosurfactant was mixed with $100 \mathrm{mg}$ of $\mathrm{KBr}$ and pressed for $30 \mathrm{~s}$, to obtain translucent pellets, and FTIR spectra were collected between 400 and 4000 wave numbers $\left(\mathrm{cm}^{-1}\right)$.

\section{High Performance Thin Layer Chromatography-Electrospray Ionization Mass Spectroscopy (HPTLC-ESI-MS)}

Biosurfactant was separated in a completely automated HPTLC system (CAMAG, Switzerland), extracted by TLC-MS interface and were analyzed directly by ESI-MS at Central Analytical and Applied Research Unit (CAARU), Sultan Qaboos University, Oman. Twenty microliter of biosurfactant $\left(0.1 \mathrm{~g} \mathrm{l}^{-1}\right)$ sample was spotted onto a HPTLC plate $(10 \mathrm{~cm} \times 10 \mathrm{~cm})$, Silica gel $60-$ $\mathrm{F}_{254}$ (Merck, Germany). The samples were spotted by automatic TLC sampler 4 (ATS 4) spotting device (CAMAG, Switzerland), using nitrogen gas. Four different solvent systems (SS) were checked for better separation of biosurfactant components: SS1: Chloroform: Methanol: Ammonium Hydroxide (65:25:4); SS2: Chloroform: Methanol: Acetone: Acetic acid (90:10:6:1); SS3: Chloroform: Methanol: Water (65:25:4); and SS4: Butanol: Acetic acid: Water (4:1:1). The HPTLC plates were separately developed using above mentioned four different solvent systems in an automatic developing chamber ADC 2 (CAMAG, Switzerland) with remote operation from winCATS software. The HPTLC plates were evaluated by TLC visualizer (CAMAG) under direct Ultra Violet (UV $254 \mathrm{~nm}$ ) light, and images were captured. The separated biosurfactant fractions were also qualitatively detected and compared by TLC scanner 4 (CAMAG, Switzerland) under UV light $(254 \mathrm{~nm})$, extracted and eluted by TLCMS interface (CAMAG, Switzerland). The TLC-MS interface head (oval, $4 \mathrm{~mm} \times 2 \mathrm{~mm}$ ) was connected to the pump (11 PLUS, HARVARD APPARATUS, Holliston, MA, USA) and the extraction was performed at a flow rate of $10 \mu \mathrm{l} / \mathrm{min}$, with methanol: acetonitrile (50\% diluted with water) - 1:10. The interface outlet was directly connected with the ESI-MS (Qaattro Ultima $^{\mathrm{TM}} \mathrm{Pt}$, Micromass $\left.{ }^{\circledast}, \mathrm{UK}\right)$. The experimental conditions were: capillary voltage, $3.0 \mathrm{kV}$; cone voltage, $35 \mathrm{~V}$; lens voltage, 


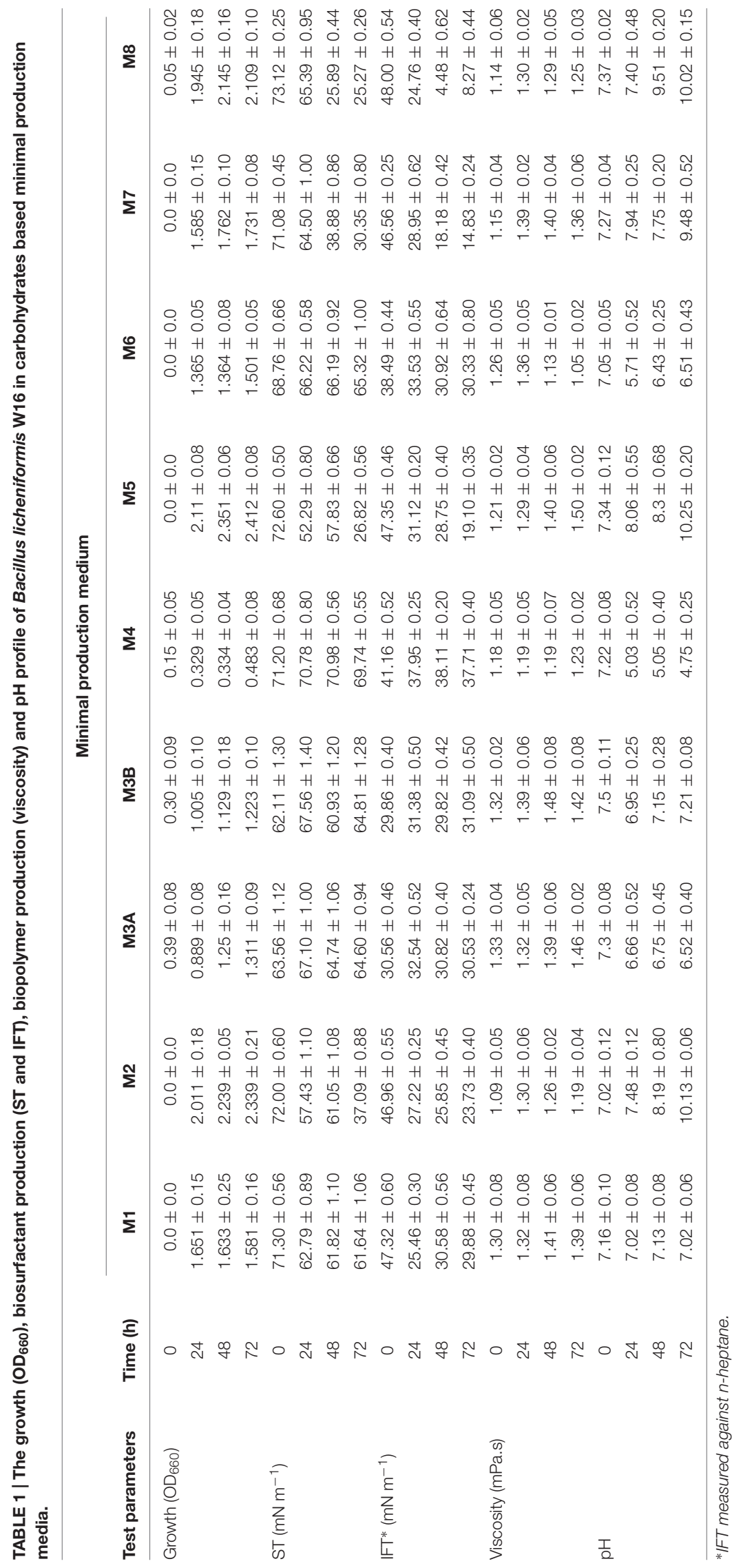



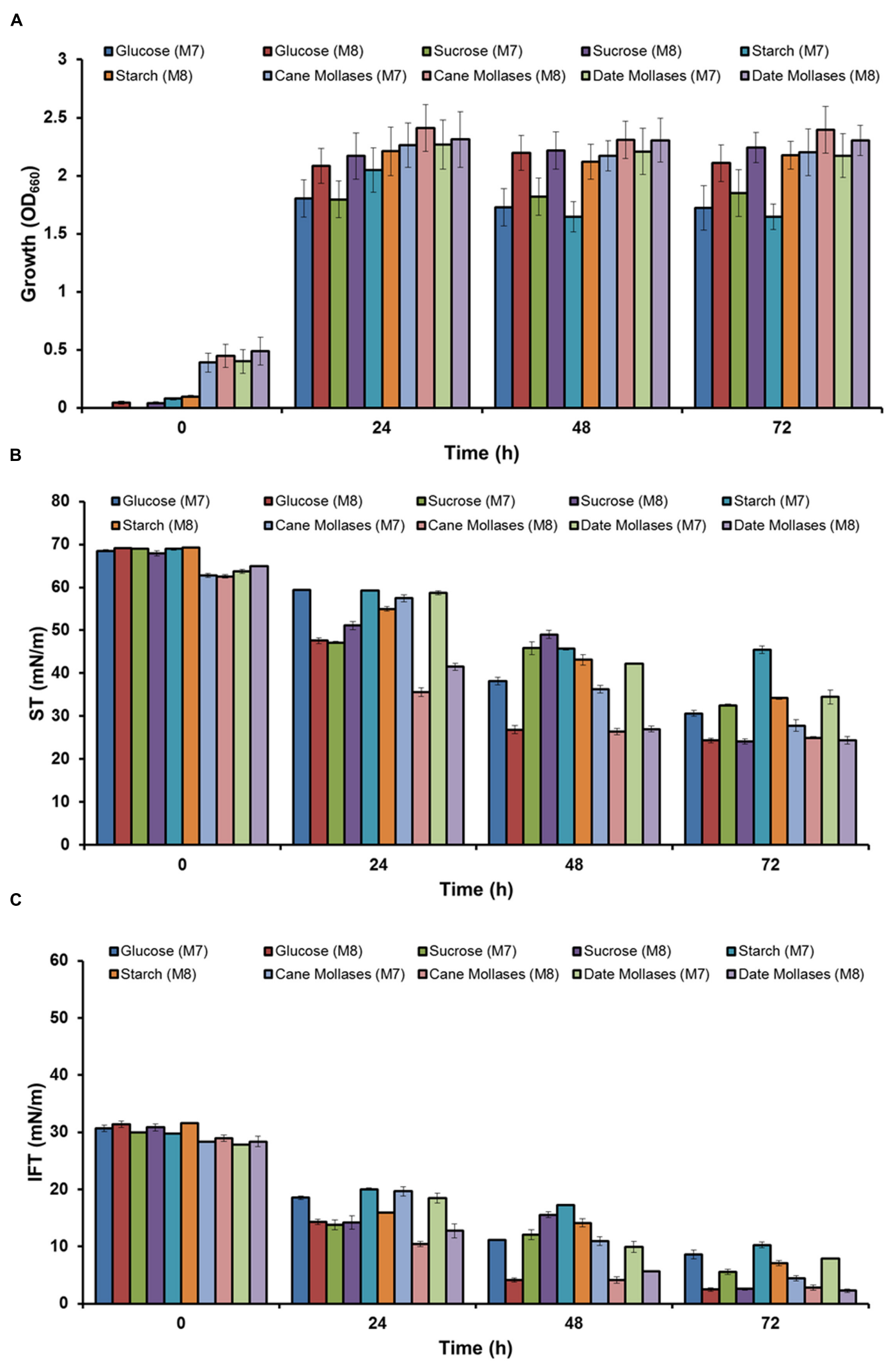

FIGURE 1 | The growth (A) and biosurfactant production profile -ST (B) and IFT (C) (against hexadecane), of Bacillus licheniformis W16 in in two minimal production media - M7 and M8 with five different carbohydrates (glucose, sucrose, starch, cane molasses, or date molasses) as a carbon source. 

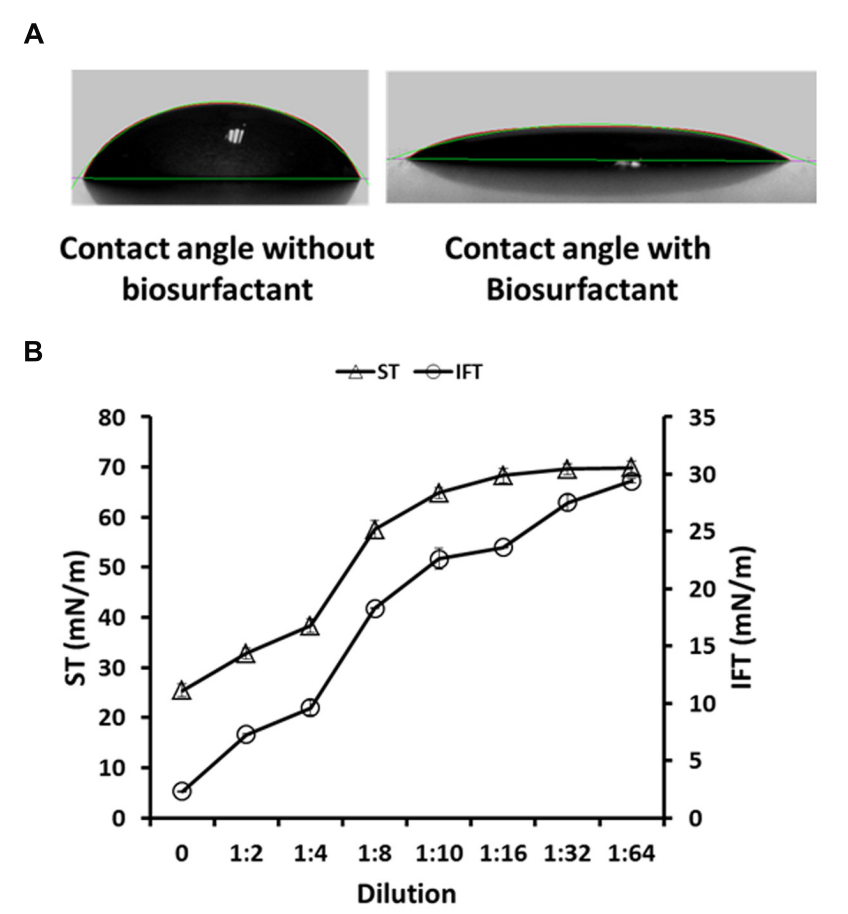

FIGURE 2 | The contact angle of abiotic control medium - without biosurfactant $\left(55.67 \pm 1.6^{\circ}\right)$, and $\mathrm{W} 16$ biosurfactant $\left(19.54 \pm 0.96^{\circ}\right)$, on a hydrophobic surface (A) and the CMD determination for W16 biosurfactant (B)

$0.0 \mathrm{~V}$; source block temperature, $100^{\circ} \mathrm{C}$; desolvation temperature, $120^{\circ} \mathrm{C}$; analyzed under both positive and negative modes in the $\mathrm{m} / \mathrm{z}$ range of 900-1200 Da, using Mass Lynx (V4.0) software.

\section{Matrix Assisted Laser Desorption lonization Time-of-Flight Mass Spectrometry Analysis (MALDI TOF-MS)}

The MALDI-TOF analysis was performed at CAARU, Sultan Qaboos University, on UltraFlextreme (Bruker Daltonics, Bremen, Germany) operating in positive reflectron mode in the $\mathrm{m} / \mathrm{z}$ range of 50-2000 Da. Two $\mu \mathrm{l}$ of 2, 5- Dihydroxy benzoic acid (DHB) matrix $(20 \mathrm{mg} / \mathrm{ml})$ in TA $30(30: 70 \mathrm{v} / \mathrm{v}$ ACN:TFA $0.1 \%$ TFA) was premixed with $2 \mu \mathrm{l}$ of the sample solution. $1 \mu \mathrm{l}$ of the sample-mixture was applied to the steel target plate, and air-dried at room temperature. The spectra were acquired using FlexControl software (v3.3), and FlexAnalysis Software (v3.3, Bruker Daltonics, Bremen, Germany) was used for visualization and initial data processing, as previously reported (Elshafie et al., 2015).

\section{Nuclear Magnetic Resonance (NMR) Analysis}

The nuclear magnetic resonance (NMR) analysis were performed at room temperature in Bruker Avance $400 \mathrm{MHz}$ spectrometer equipped with $5 \mathrm{~mm}$ BBO probe at Department of Chemistry, Sultan Qaboos University. The proton $\left({ }^{1} \mathrm{H}\right)$ NMR experiment was run using zg30 pulse program operating at $400.13 \mathrm{MHz}$. Acquisition parameter were as follows: $90^{\circ}$ proton pulse width of $14.80 \mu \mathrm{s}$, relaxation delay of $2 \mathrm{~s}, 2048$ scans. The proton decoupled ${ }^{13} \mathrm{C}$ NMR experiments were carried out using composite pulse decoupling scheme operating at $100.61 \mathrm{MHz}$. Acquisition parameter were as follows: $90^{\circ}$ proton pulse width of $9.80 \mu \mathrm{s}$, relaxation delay of 2 s, 9216 scans. The Spectra were recorded in $\mathrm{CD}_{3} \mathrm{OD}$ at $296.2 \mathrm{~K}$ and processed using XWIN 3.5 software.

\section{Biosurfactant Stability Studies}

Biosurfactant stability was studied at wide range of temperatures $\left(40-100^{\circ} \mathrm{C}\right), \mathrm{pH}(2.0-12.0)$ and different salinities $(2-15 \% \mathrm{v} / \mathrm{v})$. All control experiments were conducted at room temperature, pH 7.0 and $0 \%$ salt concentration. For the temperature stability test, the cell-free samples were filled in $10 \mathrm{ml}$ serum bottles, sealed with butyl rubber stoppers and aluminum crimps, and incubated at respective temperatures, to avoid any loss due to evaporation. The biosurfactant broth was also subjected to autoclave conditions $\left(121^{\circ} \mathrm{C}, 15 \mathrm{psi}\right.$ for $\left.30 \mathrm{~min}\right)$ in order to investigate the effect of such environment on the surface activity. To check the effect of salt concentrations, different concentrations of $\mathrm{NaCl}$ were added to cell-free biosurfactant broth, dissolved completely and incubated at room temperature. The stability of the biosurfactant was also determined by measuring the ST and IFT at different $\mathrm{pH}$ values (by addition of $6 \mathrm{~N} \mathrm{HCl}$ or $1 \mathrm{~N} \mathrm{NaOH}$ ) at room temperature.

\section{Berea Sandstone Core-Plugs and Fluid Samples}

A set of Berea sandstone cores (1.5 inch diameter $\times 3$ inch long) with average porosity and permeability of $18-22 \%$ and 250 $260 \mathrm{mD}$ respectively, were used for the core-flood experiments. The formation water and crude oil used in these experiments were provided by Petroleum Development Oman. Formation water was filtered prior to use, by Millipore Filtration Unit $(0.45 \mu \mathrm{m})$. The crude oil used for core-flood experiments was light oil with API $36.51^{\circ}$ and $1.77 \mathrm{cp}$ viscosity. The formation water was analyzed for anions, cations, and different parameters. Multi-parameter equipment (Multi 9310, WTW, Germany) was used for: conductivity, resistivity, total dissolved solids (TDS), salinity, temperature and pH meter (Jenway 3505, UK) was used for analyzing the pH; Anton Paar Density meter (DMA 4500M) was used for measuring specific gravity, as per manufacturer instructions. Anions and major cations analysis was done using Ion chromatography (850 Professional IC AnCat MCS and 858 Professional Auto sampler, Metröhm, Switzerland). For anion analysis Metrosep A Supp 7-250 (250 mm × $4.0 \mathrm{~mm})$ column was used and analyzed by MagIc Net ${ }^{\mathrm{TM}}$ software. The running conditions were: Mobile phase - $3.6 \mathrm{mM}$ Sodium carbonate; Regenerant - $200 \mathrm{mM}$ Sulfuric acid; Rinsing solution Ultrapure water; Temperature $-45^{\circ} \mathrm{C}$; Flow rate $-0.7 \mathrm{ml} / \mathrm{min}$. For cation analysis Metrosep C $4-150(150 \mathrm{~mm} \times 4.0 \mathrm{~mm})$ column was used, and analyzed by MagIc $\mathrm{Net}^{\mathrm{TM}}$ software. The running conditions were: Mobile phase - $1.7 \mathrm{mM} \mathrm{HNO}_{3}$ and $0.7 \mathrm{mM}$ DPA; Rinsing solution - Ultrapure water; Temperature $45^{\circ} \mathrm{C}$; Flow rate $-0.9 \mathrm{ml} / \mathrm{min}$. Remaining metal cation analysis was performed using - Inductively coupled plasma - mass 


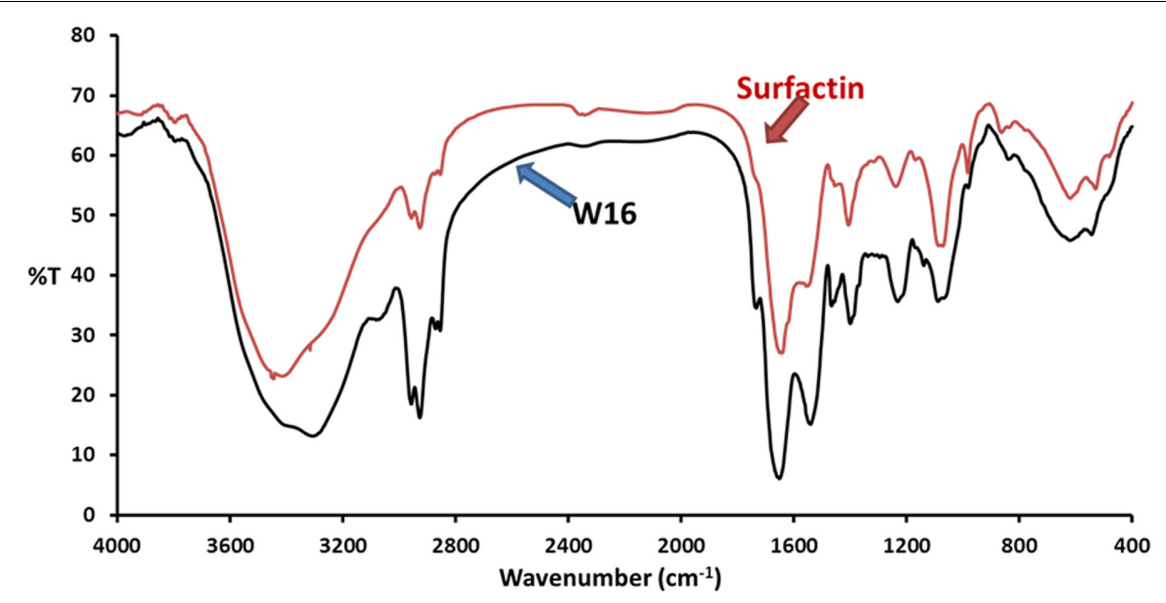

FIGURE 3 | The FTIR absorption spectra of biosurfactant produced by B. licheniformis W16, and reference standard lipopeptide biosurfactant surfactin (Sigma Chemicals, USA).

\section{A}

B
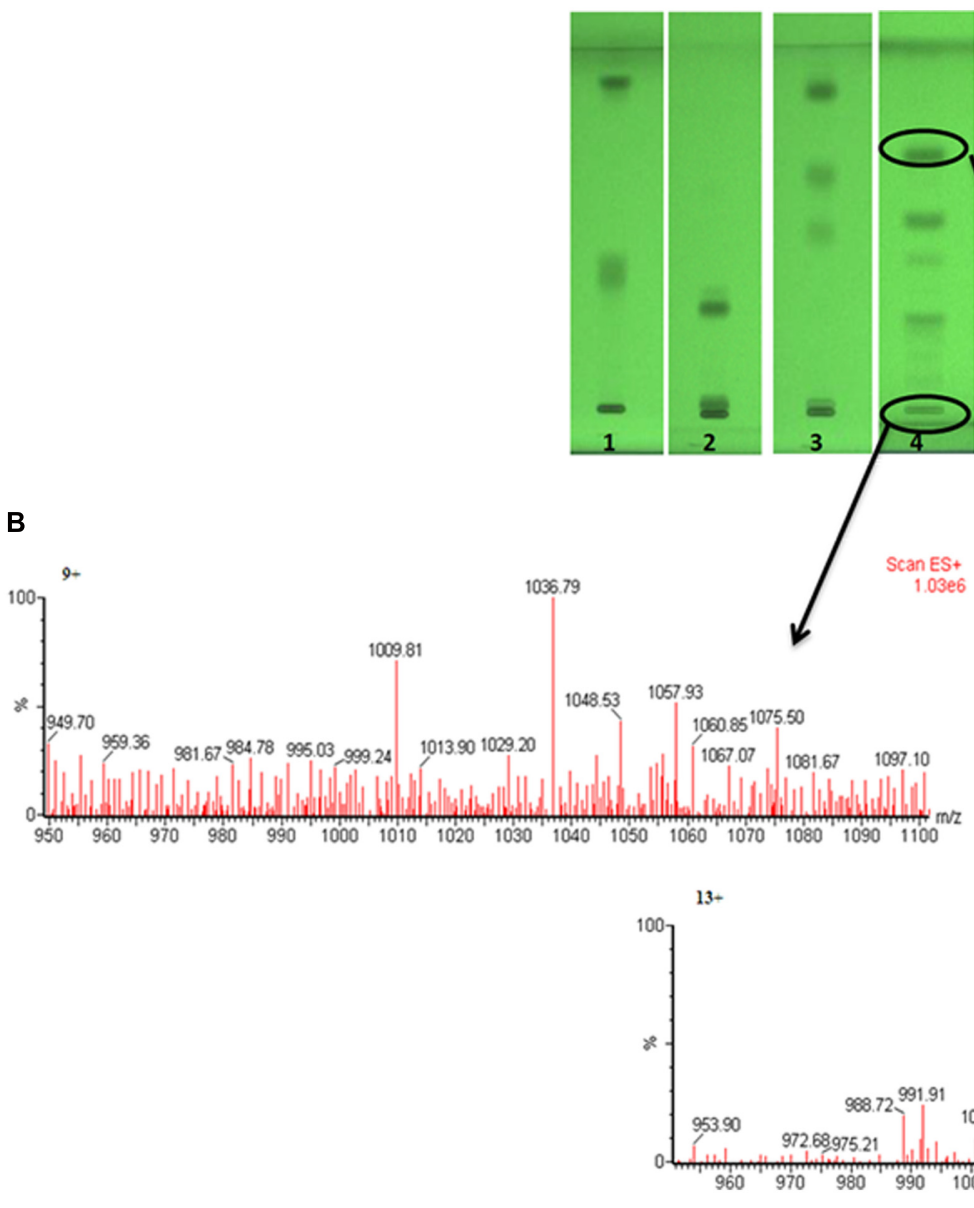

FIGURE 4 | The HPTLC plate developed with four different solvent systems, showing separated biosurfactant under UV 254 nm (A), and the mass spectra of two bands directly extracted by TLC-MS interface and analyzed by ESI-MS (B) under positive mode. 


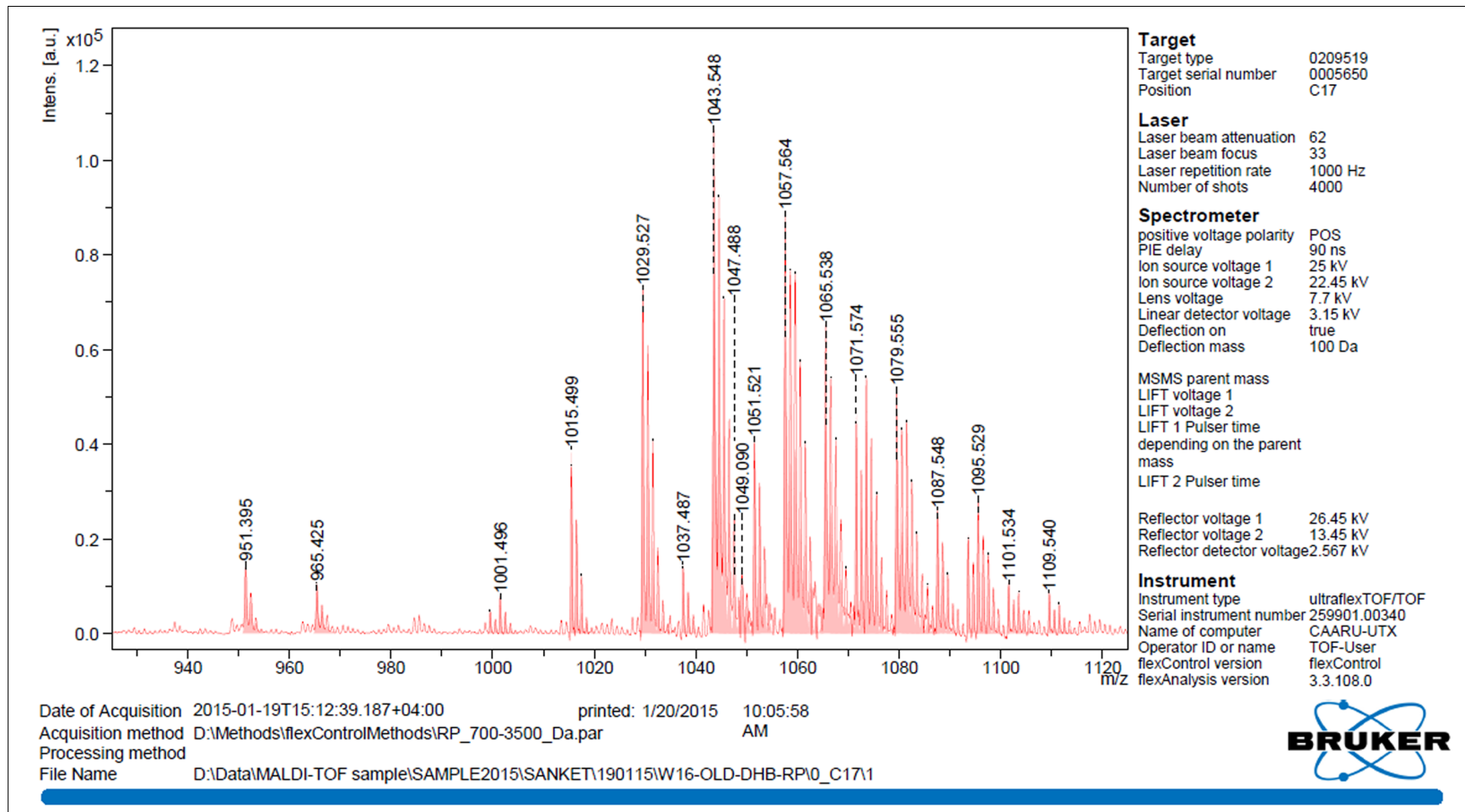

FIGURE 5 | The MALDI-TOF spectrum of biosurfactant produced by B. licheniformis W16.

spectrometer (ICP-MS, Bruker aurora M90); Mode -Aqueous Analysis; Ar Plasma Flow- 16.5 Lit Pm, Aux- 1.65 Lit Pm, Sheath0.2 Lit Pm, Neb- 1.0 Lit Pm.

\section{Core-Flood Experiments}

Prior to core-flooding experiments, all core-plugs were thoroughly cleaned by chloroform and methanol (75:25) in the Soxhlet apparatus (Al-Sulaimani et al., 2011a). After cleaning, the core-plugs were dried in a hot air oven at $65^{\circ} \mathrm{C}$ for $24 \mathrm{~h}$. The cleaned and dried core-plugs were then saturated with filtered formation brine using vacuum desiccators for $24 \mathrm{~h}$ to measure the pore volume (PV), using the dry and wet weights of the core. The core-plugs were then flooded with crude oil at $24 \mathrm{~cm}^{3} \mathrm{~h}^{-1}$ until no more brine was produced. The oil initially in place (OIIP) was determined by the volume of brine displaced with crude oil. Then, cores were brine-flooded $\left(24 \mathrm{~cm}^{3} \mathrm{~h}^{-1}\right)$ until no further oil was produced, and the residual oil was calculated by measuring the amount of oil produced from the brine-flood. Then, $5 \mathrm{PV}$ of the cell-free biosurfactant broth was injected as a tertiary recovery stage and extra oil recovery was determined. All core-flood experiments were conducted at $60^{\circ} \mathrm{C}$ to mimic the average reservoir temperature of the field of interest.

\section{RESULTS AND DISCUSSION}

Microbial enhanced oil recovery is regarded as one among the most promising green-technologies that can be potentially implemented with an exceptionally low operating cost. Several of the bacterial products are reported for playing a role in MEOR, where biopolymers and biosurfactants are reported as key players (Belyaev et al., 2004; Sen, 2008; Marchant and Banat, 2012a). Amongst different kind of biosurfactants, low molecular compounds - lipopeptides produced by sporeforming bacteria are regarded as having potential role in MEOR. Several morphologically different spore-forming bacteria were isolated from different oil contaminated soil samples collected from Oman, and screened for biosurfactant production. Out of those isolates, a facultative aerobic bacteria $B$. licheniformis W16 produced biosurfactant (Al-Sulaimani et al., 2011a) and propagated under anaerobic conditions in the fractured carbonate rocks and enhanced the oil recovery by selective plugging (Al-Hattali et al., 2013). Thus, it was further selected in current study to investigate the effect of different carbohydrates in the minimal media and the potential of produced biosurfactant in biosurfactant based MEOR. The growth and production profile in the nine different production media are shown in Table 1. The better growth was observed in media 2, 5, and 8 within $24 \mathrm{~h}$, whereas very little growth was observed in media 4 . One possible reason for little growth in media 4 could be because of the acidic $\mathrm{pH}$ after $24 \mathrm{~h}$, as compared to observed neutral to alkaline $\mathrm{pH}$ in rest of the media (Table 1), and this strain showed better growth in neutral to alkaline range (data not shown). The lowest ST and IFT values were observed in media 7 and 8 , as $25.89-38.88 \mathrm{mN} \mathrm{m}^{-1}$ and $4.48-18.88 \mathrm{mN} \mathrm{m}^{-1}$ respectively. Therefore, media 7 (M7) and 8 (M8) were further selected for carbon source optimization studies. None of the 


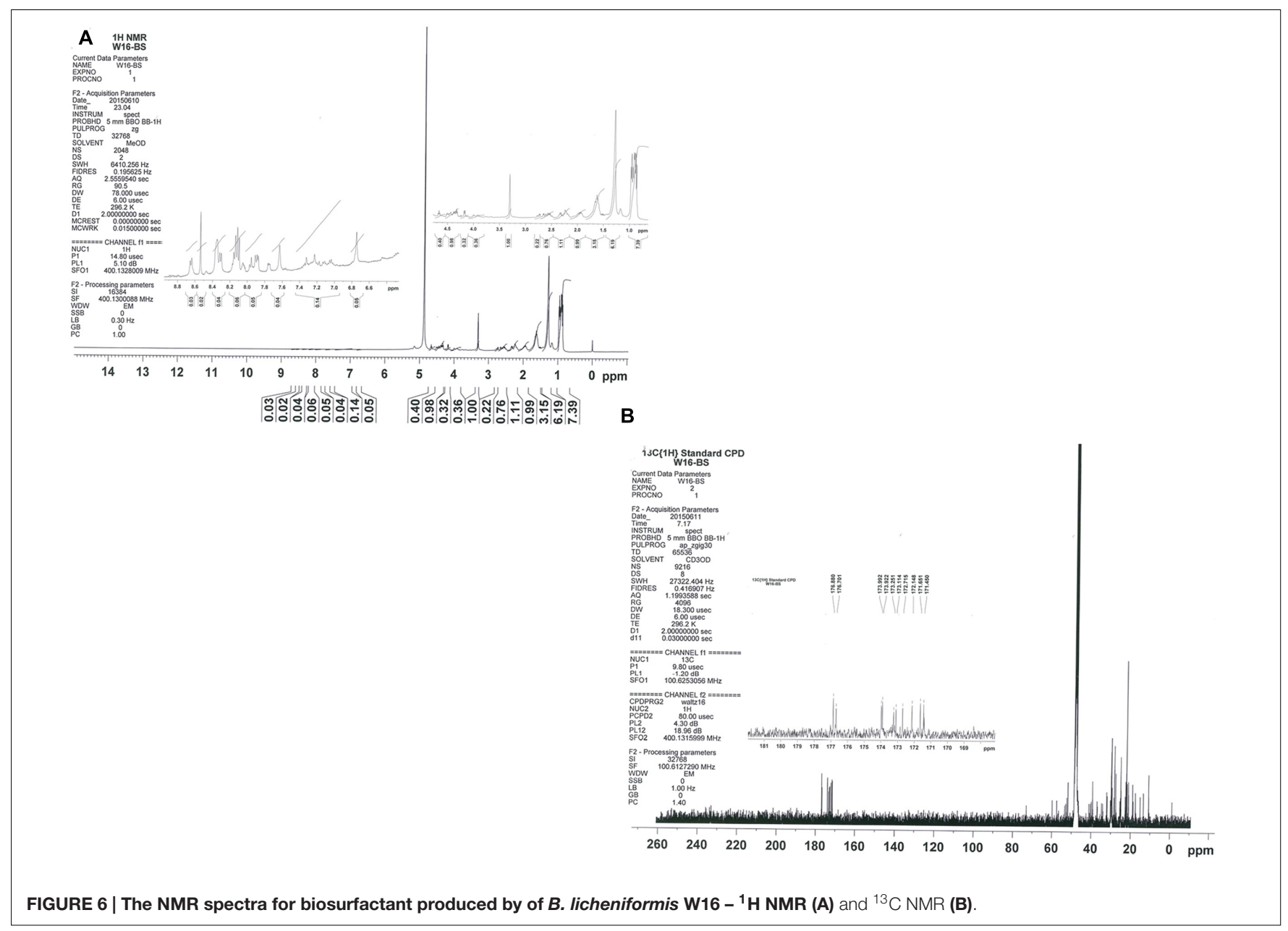

media showed much increase in the viscosities even after $72 \mathrm{~h}$, and the viscosities varied between 1.3 and $1.5 \mathrm{mPa} \mathrm{s}$, for both abiotic controls and experimental samples. The viscosities of some of the biopolymers are reported to be in the range of 43$21535 \mathrm{cP}$ (Joshi et al., 2016). Hence, it was concluded that this isolate B. licheniformis W16 produced only biosurfactant and not biopolymer, under tested environmental conditions in these nine minimal media.

As media M7 and M8 showed better growth and biosurfactant production, both media were selected for further screening of different types of carbohydrates as a carbon sources - glucose, sucrose, starch, cane moleasses, or date molasses. Better growth was observed in M8 media as compared to M7, in all five carbon sources, and highest growth $\left(\mathrm{OD}_{660}-2.3-2.4\right)$ was observed in M8 media containing cane or date molasses (Figure 1A). It was observed that in all media ST was reduced to $<35 \mathrm{mN} \mathrm{m}^{-1}$, from 62 to $70 \mathrm{mN} \mathrm{m}^{-1}$, within $72 \mathrm{~h}$ (Figure 1B), except in starch containing Media M7, where higher ST was observed $\left(45.42 \pm 0.88 \mathrm{mN} \mathrm{m}^{-1}\right)$. Similar trend was observed for IFT also, where starch containing media M7 had higher IFT $(10.27 \pm 0.52)$ as compared to all other conditions (Figure 1C). The lower ST and IFT were observed in M8 media containing glucose, cane molasses or date molasses, and glucose containing media showed the lowest ST and IFT values of $24.33 \pm 0.31 \mathrm{mN} \mathrm{m}^{-1}$ and $2.47 \pm 0.32 \mathrm{mN} \mathrm{m}^{-1}$ respectively. These observed values of ST and IFT are in accordance with several other reports by researchers for biosurfactant production by Bacillus species (Joshi et al., 2008a; Al-Bahry et al., 2013; Chandankere et al., 2013; Pereira et al., 2013). In this study, it was observed that isolate B. licheniformis W16 produced a potent biosurfactant using either glucose or cane molasses as a carbon source. Glucose based media M8 was used for biosurfactant production and further studies, as it gave better results in ST and IFT reduction.

Any alteration at the reservoir 'oil-water-rock' interface, leads to change in the surface-wettability properties (oil-wet to water-wet and vice versa), which has also been proposed as one of the mechanism responsible for EOR (Kowalewski et al., 2006; Al-Sulaimani et al., 2012; Al-Wahaibi et al., 2014). The $B$. licheniformis W16 biosurfactant produced from glucose containing M8 medium, was studied for any effect on changes in the contact angle on a hydrophobic surface (provided with the instrument - DSA 100, KRÜSS, Germany). The contact angle was reduced from $55.67 \pm 1.6^{\circ}$ of un-inoculated abiotic control media to $19.54 \pm 0.96^{\circ}$ in cell-free biosurfactant broth (Figure 2A). Karimi et al. (2012) studied the effect of microbial solutions (using an Enterobacter cloacae strain) on 7-21 days aged 


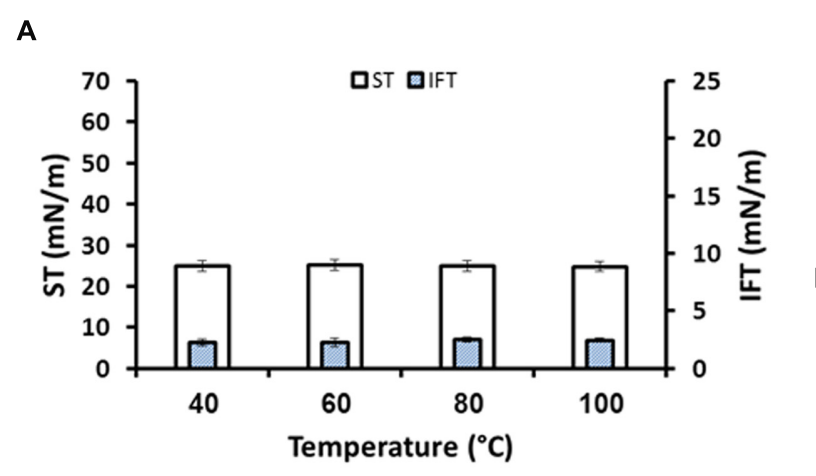

C

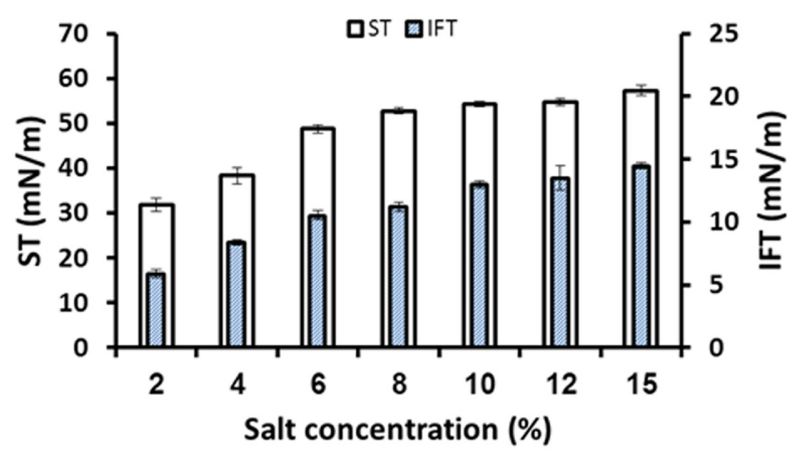

B

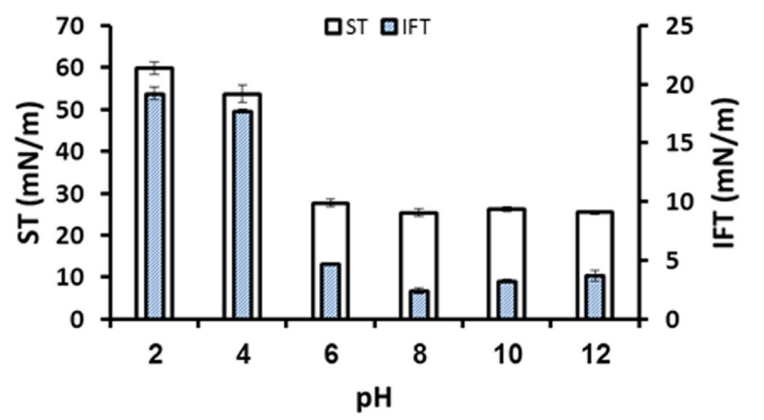

FIGURE 7 | The stability studies for biosurfactant produced by $\mathbf{B}$. licheniformis W16, under different temperatures (A), pH (B), and salinity (C).

glass surfaces, and have reported that it alters the wettability of hydrophobic glass surfaces toward more water-wet conditions. Al-Sulaimani et al. (2012) reported that biosurfactant produced by $B$. subtilis W19 changed the contact angle of distilled water from $70.6 \pm 0.3^{\circ}$ to $25.32 \pm 0.06^{\circ}$ at $0.25 \%(\mathrm{w} / \mathrm{v})$ biosurfactant. Al-Wahaibi et al. (2014) also reported changes in wettability of hydrophobic surface from $58.7 \pm 0.85^{\circ}$ to $28.4 \pm 1.03^{\circ}$ and $27.2 \pm 0.72^{\circ}$ by biosurfactant produced by B. subtilis $\mathrm{B} 30$ in glucose or molasses based minimal media. In the current study, we observed that biosurfactant changed the wettability of hydrophobic surface toward more water-wet, which is beneficial during EOR applications. To the best of our knowledge this is the first report of wettability alteration using biosurfactant produced by $B$. licheniformis strain. Along with reduction in ST and IFT, wettability alteration by W16 biosurfactant could also play an important role in improving oil recovery at field scale applications. It is reported that the dilution at which the ST/IFT begins to increase is termed the CMD, which is actually the factor by which the effective biosurfactant concentration exceeds the critical micelle concentration (Ghurye et al., 1994; Al-Wahaibi et al., 2014). The ST and IFT values increased sharply after $4 \mathrm{X}$ dilution, where the ST and IFT values observed were $38.28 \pm 1.36 \mathrm{mN} \mathrm{m}^{-1}$ and $9.61 \pm 0.65 \mathrm{mN} \mathrm{m}^{-1}$ respectively (Figure 2B). Therefore, the observed CMD values for W16 biosurfactant was 4X. Makkar and Cameotra (1997) have reported the biosurfactant production by two B. subtilis strains which reduced the ST in the range of 30-40 dynes $\mathrm{cm}^{-1}$ with $10 \mathrm{X}-100 \mathrm{X} \mathrm{CMD}$ values after $96 \mathrm{~h}$. Joshi and Desai (2013) reported CMD values of $75 X-100 X$ for biosurfactants mixtures produced by different Bacilli strains in carbohydrate based minimal media. Al-Wahaibi et al. (2014) reported CMD values of $8 \mathrm{X}$ for biosurfactant produced by B. subtilis $\mathrm{B} 30$. The CMD values observed for W16 biosurfactant was comparatively lower than biosurfactants produced by other Bacilli strains.

To determine the yield of biosurfactant, it was extracted by acid-precipitation and crude-powder was collected by spray-drying. The yield of partially purified biosurfactant was $0.52 \pm 0.1 \mathrm{~g} \mathrm{l}^{-1}$, which was used for structural identification by FTIR. The IR spectra of biosurfactants produced by B. licheniformis W16 is shown in Figure 3. The IR spectrum in $\mathrm{KBr}$ showed bands characteristic of peptides at $3300-3400 \mathrm{~cm}^{-1}$ (N-H stretching mode) and at $1650-1700 \mathrm{~cm}^{-1}$ (stretching mode of the CO-N bond). The bands at $1200-1400 \mathrm{~cm}^{-1}$ reflected the aliphatic chains $\left(-\mathrm{CH}_{3},-\mathrm{CH}_{2}-\right)$ of the isolated fraction (AlSulaimani et al., 2011a; Al-Wahaibi et al., 2014; Joshi et al., 2015). These results imply the presence of aliphatic groups as well as a peptide-like moiety in the biosurfactant. For comparison of the biosurfactant, surfactin (Sigma chemicals, USA) was also 


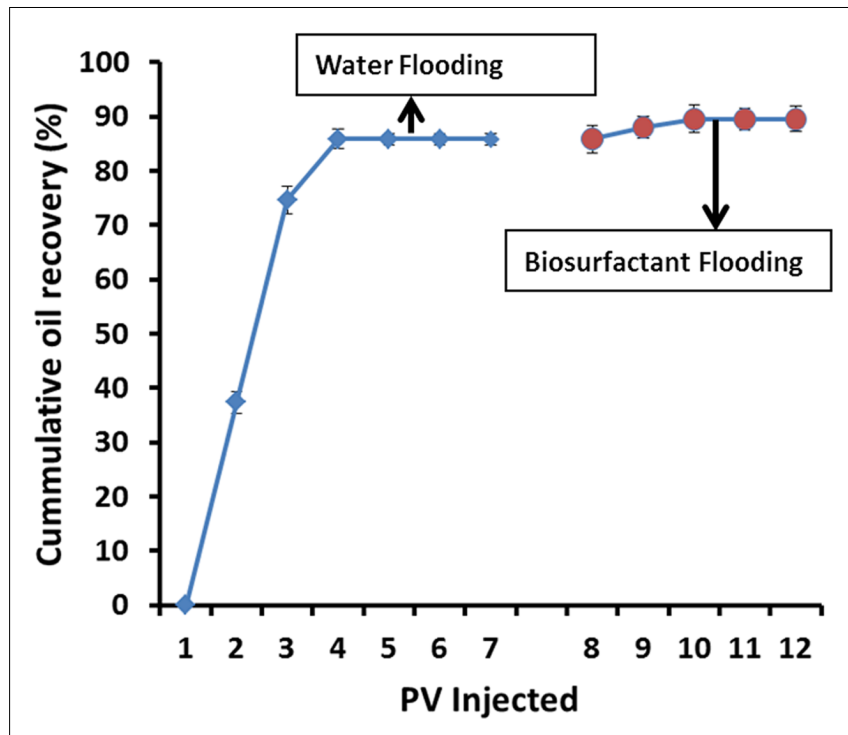

FIGURE 8 | The cumulative oil recovery (light oil - API $36.51^{\circ}$ ) from Berea sandstone core-plugs using biosurfactant.

analyzed by FTIR (Figure 3 ). The IR spectrum of surfactin and W16 biosurfactant was quite similar, which suggested the similarity in the structure of the biosurfactant produced by B. licheniformis W16 with lipopeptide surfactin. Structurally, similar lipopeptide biosurfactants - surfactins and lichenysins are reported as excellent surface active agents with potential in EOR applications (Jean-Marc et al., 2003).

Out of four solvent systems used for HPTLC, SS4 gave better separation (Figure 4A) as compared to SS1, SS2, and SS3; hence, we used solvent system - SS4 for further characterization of biosurfactant. The TLC or HPTLC are reported as quite useful tool for initial qualitative or quantitative analysis of different types of biosurfactants (Mukherjee et al., 2009b; Ismail et al., 2013; Al-Wahaibi et al., 2014). We further utilized TLC-MS interface for extraction and elution of separated biosurfactant bands and analyzed them directly by ESI - MS under positive and negative modes. Total five major bands were scrapped, eluted and analyzed by ESI-MS. The mass spectra (Figure 4B) revealed the major group of peaks at $\mathrm{m} / \mathrm{z}$ values between 1000 and 1090 (The mass spectra of remaining bands are as Supplementary Figure S1). This group could be attributed to the different variants of surfactins or lichenysins, as previously described (Pereira et al., 2013; Al-Wahaibi et al., 2014; Joshi et al., 2015). The HPTLC-ESI-MS is quite easy and quick technique to identify the biosurfactants. To further confirm the identity of different biosurfactant isoforms, biosurfactant was analyzed using MALDI-TOF-MS.

MALDI-TOF mass spectrum of the biosurfactant produced by $B$. licheniformis W16 is shown in Figure 5. The observed main peaks were similar to the molecular masses of known lipopeptides - lichensyin and their homologs (Horowitz and Griffin, 1991; Mikkola et al., 2000; Li et al., 2008; Nerurkar, 2010; Madslien et al., 2013; Pereira et al., 2013; Zhang et al., 2014). There were a total of 12 main peaks with the $\mathrm{m} / \mathrm{z}$ value as 1015.5-1087.5. Considering the molecular mass of different homologs of lichenysin $\left(\mathrm{C}_{12}-\mathrm{C}_{16}\right)$, these peaks were identified as protonated ions $[\mathrm{M}+\mathrm{H}]+m / z$ 1049.1; sodium adduct ions $[\mathrm{M}+\mathrm{Na}]^{+}$with $\mathrm{m} / z$ of $1015.5,1029.5,1043.5$, and 1057.6; sodium adducts $[\mathrm{M}-\mathrm{H}+2 \mathrm{Na}]^{+}$with $\mathrm{m} / z$ of $1051.5,1065.5$, and 1079.5; potassium adducts $[\mathrm{M}+\mathrm{K}]+$ with $\mathrm{m} / \mathrm{z}$ of 1087.5. MALDI-TOF analysis of W16 biosurfactant showed similarity with lichenysin-A, produced by $B$. licheniformis strains (Grangemard et al., 1999; Mikkola et al., 2000; Li et al., 2008; Zhang et al., 2014; Joshi et al., 2015). They have reported that lichenysin - A is a cyclic heptalipopeptide having a small peptide (Gln, Leu, Leu, Val, Asp, Leu, and Ile) linked to 3-hydroxy fatty acid residue with amide (Gln) and lactone (Ile) bonds forming a cyclic structure, with main fatty acids are 3-hydroxylated tri, tetra, penta, and hexadecanoic acids.

The results obtained with ${ }^{1} \mathrm{H}$ NMR (Figure 6A) further confirmed the lipopeptide nature of the molecule. Seven amide (-NH-) groups were observed in the region from 8.4 to $7.4 \mathrm{ppm}$, and the alpha-hydrogen ( $\mathrm{H} \alpha \mathrm{s}$ ) of the amino acids showed resonance from 4.7 to $3.8 \mathrm{ppm}$. A doublet at $\delta=0.904 \mathrm{ppm}$ was observed, which indicated a terminal branching in the fatty acyl chain $\left[-\left(\mathrm{CH}_{3}\right)_{2}-\mathrm{CH}-\right]$. Other multiplets in the upfield region arise as a result of the side chain protons of the amino acids, and remaining spectra confirmed the presence of $\beta$-hydroxy fatty acid. The ${ }^{13} \mathrm{C}$-NMR spectrum showed strong signals at 10.744-17.527, 18.638-59.817, and 171.450176.880 ppm from methyl, methylene, and carboxyl group, respectively (Figure 6B). Therefore, the biosurfactant produced by $B$. licheniformis W16 was characterized as lipopeptide, similar to lichenysin-A (Horowitz and Griffin, 1991; Lin et al., 1994; Makkar and Cameotra, 1999; Saimmai et al., 2013; Zhang et al., 2014; Joshi et al., 2015).

Any chemical agents to be used for EOR needs to be stable within a range of high temperatures $\left(>40^{\circ} \mathrm{C}\right)$, wide range of $\mathrm{pH}$ and salinities. Therefore, the biosurfactant produced by $B$. licheniformis W16 was studied for its stability at wide range of harsh environmental conditions normally encountered in oil reservoirs. The biosurfactant was quite stable over a wide range of temperatures from 40 to $100^{\circ} \mathrm{C}$ (Figure 7A), and also was stable at temperatures higher than $100^{\circ} \mathrm{C}\left(121^{\circ} \mathrm{C}\right.$ when subjected to autoclaving conditions; and at $100-160^{\circ} \mathrm{C}$ during drying-extraction using spray-dryer). The W16 biosurfactant was also stable in $\mathrm{pH}$ range of 6-12 and salt concentration up to $4 \% \mathrm{NaCl}$ (Figures 7B,C). Under highly acidic $\mathrm{pH}(\mathrm{pH} \leq 4.0)$ biosurfactant was precipitated and thus higher ST and IFT values were observed. Several researchers also reported the stability of biosurfactants under high temperatures, at different $\mathrm{pH}$ values and salinities (Gudina et al., 2010; Khopade et al., 2012; Vaz et al., 2012; Saimmai et al., 2013; Al-Wahaibi et al., 2014; Jha et al., 2016).

Several mechanisms are reported for MEOR such as - selective plugging of highly porous rocks, reducing the viscosity of heavy oil by biodegradation, reduction of ST and IFT, wettability alteration etc. Previously, Al-Hattali et al. (2013) reported the potential of $B$. licheniformis W16 in enhancing the oil recovery in fractured carbonate rocks by growth under anaerobic conditions and selectively plugging the highly porous rock after $11 \mathrm{~h}$ 
incubation under reservoir conditions. They reported $27-30 \%$ additional oil recovery over residual oil saturation by microbial permeability profile modification (MPPM). In this study, the ex situ produced biosurfactant by $B$. licheniformis W16 was used for core-flooding studies using Berea sandstone core-plugs under reservoir conditions.

The salinity of the formation water was between 7 and $9 \%, \mathrm{pH}$ $\sim 6.9$, TDS $\sim 71000-72000 \mathrm{ppm}$, and major ions were $\left(\mathrm{kg} \mathrm{m}^{-3}\right)$ : Sodium, 20.2-20.7; Calcium, 3.96-4.52; Magnesium, 0.95-1.02; Iron, 5; Chloride, 41.8-43.2; Sulfate, 0.33-0.35, Bromide, 0.300.31 (concentration of other ions and complete water chemistry can be found in Supplementary Table S1).

For core-flood experiments, cell-free biosurfactant broth was used. The pore volumes of the core-plugs were $17-19 \mathrm{~cm}^{3}$. Initial oil saturation $\left(\mathrm{So}_{\mathrm{i}}\right)$ in cores after oil flooding was around 73$77 \%$, and after $7 \mathrm{PV}$ of brine injection, nearly $80-85 \%(\cong 11.5 \mathrm{ml})$ of oil was produced and residual oil saturation $\left(\mathrm{So}_{\mathrm{r}}\right)$ was about 15-20\%. Extra oil recovery was observed after injecting 4-5 PV of biosurfactant solution, where $24-26 \%(\cong 0.5 \mathrm{ml})$ of $\mathrm{So}_{\mathrm{r}}$ was produced (Figure 8). Other researchers have reported $20-37 \%$ additional oil recovery over the residual oil saturation using cell-free biosurfactant injection in the core-plugs or sand-pack columns (Yakimov et al., 1997; Almeida et al., 2004; Al-Sulaimani et al., 2011a; Darvishi et al., 2011; Joshi and Desai, 2013; AlWahaibi et al., 2014; Arora et al., 2014; Elshafie et al., 2015; Joshi et al., 2015; Jha et al., 2016). In present study, the additional oil recovered could be due to mechanisms like reduction in ST/IFT and/or due to wettability alteration at the rock-oil-water interface, as observed during the course of study.

\section{CONCLUSION}

To isolate $B$. licheniformis W16 produced a potent lipopeptide biosurfactant, within $48-72 \mathrm{~h}$ in carbohydrate based minimal media. It reduced ST, IFT and also altered the wettability thus changing the hydrophobic surface to more water-wet. To the best of our knowledge this is the first report of wettability alteration using biosurfactant produced by $B$. licheniformis strain. The biosurfactant produced by $B$. licheniformis W16 was characterized as lipopeptide, similar to lichenysin-A. It was

\section{REFERENCES}

Al-Bahry, S. N., Al-Wahaibi, Y., Elshafie, A., Al-Bemani, A., Joshi, S., AlMakhmari, H., et al. (2013). Biosurfactant production by Bacillus subtilis B20 using date molasses and its possible application in enhanced oil recovery. Int. Biodeterior. Biodegradation 81, 141-146. doi: 10.1016/j.ibiod.2012.01.006

Al-Hattali, R., Al-Sulaimani, H., Al-Wahaibi, Y., Al-Bahry, S., Elshafie, A., AlBemani, A., et al. (2013). Fractured carbonate reservoirs sweep efficiency improvement using microbial biomass. J. Petrol. Sci. Eng. 112, 178-184. doi: 10.1016/j.petrol.2013.11.003

Almeida, P. F., Moreira, R. S., Almeida, R. C., Guimarães, A. K., Carvalho, A. S., Quintella, C., et al. (2004). Selection and application of microorganisms to improve oil recovery. Eng. Life Sci. 4, 319-325. doi: 10.1002/elsc.200420033

Al-Sulaimani, H., Al-Wahaibi, Y., Al-Bahry, S. N., Elshafie, A., Al-Bemani, A., Joshi, S., et al. (2011a). Optimization and partial characterization of biosurfactant produced by Bacillus species and their potential for enhanced oil recovery. SPE J. 16, 672-682. doi: 10.2118/129228-PA quite stable under wide range of harsh reservoir conditions like high temperatures, $\mathrm{pH}$ range and salinities. It also successfully produced around $24-26 \%$ of residual oil $\left(\mathrm{S}_{\mathrm{or}}\right)$ from Berea sandstone core-plugs at $60^{\circ} \mathrm{C}$. Further scale-up studies are recommended to better understand the economics of the biosurfactant applications at pilot-scale.

\section{AUTHOR CONTRIBUTIONS}

Conceived and designed the experiments: SJ, YA-W, SA-B, AE, ASA-B. Provided all the resources for performing experiments: YA-W, SA-B, AE, ASA-B, MA-M. Performed the experiments: SJ, AA-B. Analyzed the data: SJ, YA-W, SA-B, AE, ASA-B, AA-B. Drafting the work, revising it critically for important intellectual content, and final approval of the version to be published: all authors.

\section{FUNDING}

The authors would like to acknowledge the support of Petroleum Development Oman with grant number CR/SCI/BIOL/11/01. The funders had no role in study design, data collection and analysis, decision to publish, or preparation of the manuscript.

\section{ACKNOWLEDGMENTS}

Authors also kindly acknowledge Mr. Khalid Al-Maqbali, Department of Chemistry, Sultan Qaboos University, for NMR analysis, and Dr. Premkumar Samuel for MALDI-TOF analysis, Central Analytical and Applied Research Unit, Sultan Qaboos University, Oman.

\section{SUPPLEMENTARY MATERIAL}

The Supplementary Material for this article can be found online at: http://journal.frontiersin.org/article/10.3389/fmicb. 2016.01853/full\#supplementary-material

Al-Sulaimani, H., Al-Wahaibi, Y., Al-Bahry, S. N., Elshafie, A., Al-Bemani, A., Joshi, S., et al. (2012). Residual oil recovery via injection of biosurfactant, chemical surfactant and mixtures of both under reservoir condition: induced wettability and interfacial tension effects. SPE Res. Eval. Eng. 15, 210-217.

Al-Sulaimani, H., Joshi, S., Al-Wahaibi, Y., Al-Bahry, S. N., Elshafie, A., and Al-Bemani, A. (2011b). Microbial biotechnology for enhancing oil recovery: current developments and future prospects. Biotechnol. Bioinf. Bioeng. J. 1, $147-158$.

Al-Wahaibi, Y., Joshi, S., Al-Bahry, S., Elshafie, A., Al-Bamani, A., and Shibulal, B. (2014). Biosurfactant production by Bacillus subtilis B30 and its application in enhancing oil recovery. Colloids Surf. B 114, 324-333. doi: 10.1016/j.colsurfb. 2013.09.022

Arora, P., Ranade, D. R., and Dhakephalkar, P. K. (2014). Development of a microbial process for the recovery of petroleum oil from depleted reservoirs at 91-96 ${ }^{\circ}$ C. Bioresour. Technol. 165, 274-278. doi: 10.1016/j.biortech.2014. 03.109 
Banat, I. M., Franzetti, A., Gandolfi, I., Bestetti, G., Martinotti, M. G., Fracchia, L., et al. (2010). Microbial biosurfactants production, applications and future potential. Appl. Microbiol. Biotechnol. 87, 427-444. doi: 10.1007/s00253-0102589-0

Belyaev, S. S., Borzenkov, I. A., Nazina, T. N., Rozanova, E. P., Glumov, I. F., Ibatullin, R. R., et al. (2004). Use of microorganisms in the biotechnology for the enhancement of oil recovery. Microbiology 73, 590-598. doi: 10.1023/B: MICI.0000044250.21076.0e

Chandankere, R., Yao, J., Choi, M. M., Masakorala, K., and Chan, Y. (2013). An efficient biosurfactant-producing and crude-oil emulsifying bacterium Bacillus methylotrophicus USTBa isolated from petroleum reservoir. Biochem. Eng. J. 74, 46-53. doi: 10.1016/j.bej.2013.02.018

Chooklin, C. S., Petmeaun, S., Maneerat, S., and Saimmai, A. (2014). Isolation and characterization of a biosurfactant from Deinococcus caeni PO5 using jackfruit seed powder as a substrate. Ann. Microbiol. 64, 1007-1020. doi: 10.1007/s13213013-0738-2

Cooper, D. G., Macdonald, C. R., Duff, S. J., and Kosaric, N. (1981). Enhanced production of surfactin from Bacillus subtilis by continuous product removal and metal cation addition. Appl. Environ. Microbiol. 42, 408-412.

Darvishi, P., Ayatollahi, S., Mowla, D., and Niazi, A. (2011). Biosurfactant production under extreme environmental conditions by an efficient microbial consortium, ERCPPI-2. Colloids Surf. B. 84, 292-300. doi: 10.1016/j.colsurfb. 2011.01.011

Desai, J. D., and Banat, I. M. (1997). Microbial production of surfactants and their commercial potential. Microbiol. Mol. Biol. Rev. 61, 47-64.

Elshafie, A. E., Joshi, S. J., Al-Wahaibi, Y. M., Al-Bemani, A. S., Al-Bahry, S. N., Al-Maqbali, D., et al. (2015). Sophorolipids production by Candida bombicola ATCC 22214 and its potential application in microbial enhanced oil recovery. Front. Microbiol. 6:1324. doi: 10.3389/fmicb.2015.01324

Ghurye, G. L., Vipulanandan, C., and Wilson, R. C. (1994). A practical approach to biosurfactant production using nonaseptic fermentation of mixed cultures. Biotechnol. Bioeng. 44, 661-666. doi: 10.1002/bit.2604 40514

Grangemard, I., Bonmatin, J. M., Bernillon, J., Das, B. C., and Peypoux, F. (1999). Lichenysins G, a novel family of lipopeptide biosurfactants from Bacillus licheniformis IM 1307: production, isolation and structural evaluation by NMR and mass spectrometry. J. Antibiot. (Tokyo) 52, 363-373. doi: 10.7164/ antibiotics.52.363

Gudina, E., Teixeira, J., and Rodrigues, L. (2010). Isolation and functional characterization of a biosurfactant produced by Lactobacillus paracasei. Colloids Surf. B 76, 298-304. doi: 10.1016/j.colsurfb.2009.11.008

Horowitz, S., and Griffin, W. M. (1991). Structural analysis of Bacillus licheniformis 86 surfactant. J. Ind. Microbiol. 7, 45-52. doi: 10.1007/BF01575602

Ismail, W., Al-Rowaihi, I. S., Al-Humam, A. A., Hamza, R. Y., El Nayal, A. M., and Bououdina, M. (2013). Characterization of a lipopeptide biosurfactant produced by a crude-oil-emulsifying Bacillus sp. I-15. Int. Biodeterior. Biodegradation. 84, 168-178. doi: 10.1016/j.ibiod.2012.04.017

Jean-Marc, B., Laprevote, O., and Peypoux, F. (2003). Diversity among microbial cyclic lipopeptides: iturins and surfactins. Activity-Structure relationships to design new bioactive agents. Comb. Chem. High Throughput Screen. 6, 541-556.

Jenny, K., Kappeli, O., and Fiechter, A. (1991). Biosurfactant from Bacillus licheniformis: structural analysis and characterization. Appl. Microbiol. Biotechnol. 36, 5-13. doi: 10.1007/BF00164690

Jha, S. S., Joshi, S. J., and Geetha, S. J. (2016). Lipopeptide production by Bacillus subtilis R1 and its possible applications. Braz. J. Microbiol. 47, 955-964. doi: 10.1016/j.bjm.2016.07.006

Joshi, S., Bharucha, C., Jha, S., Yadav, S., Nerurkar, A., and Desai, A. J. (2008a). Biosurfactant production using substrates from renewable-resources, molasses and whey under thermophilic conditions. Bioresour. Technol. 99, 195-199. doi: 10.1016/j.biortech.2006.12.010

Joshi, S., Yadav, S., and Desai, A. J. (2008b). Application of response surface methodology to evaluate the optimum medium components for the enhanced production of lichenysin by B. licheniformis R2. Biochem. Eng. J. 41, 122-127. doi: 10.1016/j.bej.2008.04.005

Joshi, S., Yadav, S., Nerurkar, A., and Desai, A. J. (2007). Statistical optimization of medium components for the production of biosurfactant by Bacillus licheniformis K51. J. Microbiol. Biotechnol. 17, 313-319.
Joshi, S. J., Al-Wahaibi, Y. M., Al-Bahry, S., Elshafie, A., Al-Bemani, A. S., Al-Hashmi, A., et al. (2016). "Production and application of schizophyllan in microbial enhanced heavy oil recovery," in Proceedings of the SPE EOR Conference at Oil and Gas West Asia, (Richardson, TX: Society of Petroleum Engineers).

Joshi, S. J., and Desai, A. J. (2013). Bench-scale production of biosurfactants and its potential in ex-situ MEOR application. Soil Sediment. Contam. 22, 701-715. doi: 10.1080/15320383.2013.756450

Joshi, S. J., Geetha, S. J., and Desai, A. J. (2015). Characterization and application of biosurfactant produced by Bacillus licheniformis R2. Appl. Biochem. Biotechnol. 177, 346-361. doi: 10.1007/s12010-015-1746-4

Karimi, M., Mahmoodi, M., Niazi, A., Al-Wahaibi, Y., and Ayatollahi, S. (2012). Investigating wettability alteration during MEOR process, a micro/macro scale analysis. Colloids Surf. B 95, 129-136. doi: 10.1016/j.colsurfb.2012.02.035

Khopade, A., Biao, R., Liu, X., Mahadik, K., Zhang, L., and Kokare, C. (2012). Production and stability studies of the biosurfactant isolated from marine Nocardiopsis sp. B4. Desalination 285, 198-204. doi: 10.1016/j.desal.2011.10. 002

Kowalewski, E., Rueslatten, I., Steen, K. H., Bodtker, G., and Torsaeter, O. (2006). Microbial improved oil recovery- bacterial induced wettability and interfacial tension effects on oil production. J. Pet. Sci. Eng. 52, 275-286. doi: 10.1016/j. petrol.2006.03.011

Landy, M. G., Warren, H., Rosenman, S. B., and Colio, L. G. (1948). Bacillomycin, an antibiotic from Bacillus subtilis active against pathogenic fungi. Proc. Soc. Exp. Biol. Med. 67, 539-541. doi: 10.3181/00379727-67-16367

Li, Y. M., Haddad, N. I., Yang, S. Z., and Mu, B. Z. (2008). Variants of lipopeptides produced by Bacillus licheniformis HSN221 in different medium components evaluated by a rapid method ESI-MS. Int. J. Pept. Res. Ther. 14, 229-235. doi: 10.1007/s10989-008-9137-0

Lin, S. C., Minton, M. A., Sharma, M. M., and Georgiou, G. (1994). Structural and immunological characterization of a biosurfactant produced by Bacillus licheniformis JF-2. Appl. Environ. Microbiol. 60, 31-38.

Madslien, E. H., Rønning, H. T., Lindbäck, T., Hassel, B., Andersson, M. A., and Granum, P. E. (2013). Lichenysin is produced by most Bacillus licheniformis strains. J. Appl. Microbiol. 115, 1068-1080. doi: 10.1111/jam.12299

Makkar, R. S., and Cameotra, S. C. (1997). Utilization of molasses for biosurfactant production by two Bacillus strains at thermophilic conditions. J. Am. Oil Chem. Soc. 74, 887-889. doi: 10.1007/s11746-997-0233-7

Makkar, R. S., and Cameotra, S. S. (1999). Structural characterization of a biosurfactant produced by Bacillus subtilis at $45^{\circ}$ C. J. Surfactants. Deterg. 2 , 367-372. doi: 10.1007/s11743-999-0091-6

Makkar, R. S., Cameotra, S. S., and Banat, I. M. (2011). Advances in utilization of renewable substrates for biosurfactant production. AMB Express 1, 1-19. doi: 10.1186/2191-0855-1-5

Marchant, R., and Banat, I. M. (2012a). Microbial biosurfactants: challenges and opportunities for future exploitation. Trends Biotechnol. 30, 558-565. doi: 10. 1016/j.tibtech.2012.07.003

Marchant, R., and Banat, I. M. (2012b). Biosurfactants: a sustainable replacement for chemical surfactants? Biotechnol. Lett. 34, 1597-1605. doi: 10.1007/s10529012-0956-x

Mikkola, R., Kolari, M., Andersson, M. A., Helin, J., and Salkinoja-Salonen, M. S. (2000). Toxic lactonic lipopeptide from food poisoning isolates of Bacillus licheniformis. Eur. J. Biochem. 267, 4068-4074. doi: 10.1046/j.1432-1033.2000. 01467.x

Mukherjee, S., Das, P., and Sen, R. K. (2009a). Rapid quantification of a microbial surfactant by a simple turbidometric method. J. Microbiol. Methods 76, 38-42. doi: 10.1016/j.mimet.2008.09.010

Mukherjee, S., Das, P., Sivapathasekaran, C., and Sen, R. (2009b). Antimicrobial biosurfactants from marine Bacillus circulans: extracellular synthesis and purification. Lett. Appl. Microbiol. 48, 281-288. doi: 10.1111/j.1472-765X.2008. 02485.x

Nerurkar, A. S. (2010). Structural and molecular characteristics of lichenysin and its relationship with surface activity. Adv. Exp. Med. Biol. 672, 304-315. doi: 10.1007/978-1-4419-5979-9_23

Pereira, J. F., Gudiña, E. J., Costa, R., Vitorino, R., Teixeira, J. A., Coutinho, J. A., et al. (2013). Optimization and characterization of biosurfactant production by Bacillus subtilis isolates towards microbial enhanced oil recovery applications. Fuel 111, 259-268. doi: 10.1016/j.fuel.2013.04.040 
Saimmai, A., Udomsilp, S., and Maneerat, S. (2013). Production and characterization of biosurfactant from marine bacterium Inquilinus limosus KB3 grown on low-cost raw materials. Ann. Microbiol. 63, 1327-1339. doi: 10.1007/s13213-012-0592-7

Sekon, K. K., and Rahman, P. K. (2014). Rhamnolipid biosurfactants-past, present and future scenario of global market. Front. Microbiol. 5:454. doi: 10.3389/ fmicb.2014.00454

Sen, R. (2008). Biotechnology in petroleum recovery: the microbial EOR. Progress Ener. Combust. Sci. 34, 714-724. doi: 10.1016/j.pecs.2008.05.001

Sen, R., and Swaminathan, T. (2004). Response surface modeling and optimization to elucidate the effects of inoculum age and size on surfactin production. Biochem. Eng. J. 21, 141-148. doi: 10.1016/j.bej.2004.06.006

Vaz, D. A., Gudiña, E. J., Alameda, E. J., Teixeira, J. A., and Rodrigues, L. R. (2012). Performance of a biosurfactant produced by a Bacillus subtilis strain isolated from crude oil samples as compared to commercial chemical surfactants. Colloids Surf. B 89, 167-174. doi: 10.1016/j.colsurfb.2011.09.009

Yakimov, M. M., Amro, M. M., Bock, M., Boseker, K., Fredrickson, H. L., Lessel, D. G., et al. (1997). The potential of Bacillus licheniformis strains for in situ enhanced oil recovery. J. Petrol. Sci. Eng. 18, 147-160. doi: 10.1016/S09204105(97)00015-6

Youssef, N., Simpson, D. R., Duncan, K. E., McInerney, M. J., Flomsbee, M., Fincher, T., et al. (2007). In situ biosurfactant production by Bacillus strains injected into a limestone petroleum reservoir. Appl. Envron. Microbiol. 73, 1239-1247. doi: 10.1128/AEM.02264-06
Youssef, N. H., Duncan, K. E., and McInerney, M. J. (2005). Importance of 3-Hydroxy fatty acid composition of lipopeptides for biosurfactant activity. Appl. Environ. Microbiol. 71, 7690-7695. doi: 10.1128/AEM.71.12.7690-7695. 2005

Zahner, R. L., Tapper, S., Marcotte, B. W., and Govreau, B. R. (2011). "What has been learned from a hundred MEOR applications," in Proceedings of the SPE Enhanced Oil Recovery Conference, (Richardson, TX: Society of Petroleum Engineers).

Zhang, R., Wu, Q., Xu, Y., and Qian, M. C. (2014). Isolation, identification, and quantification of lichenysin, a novel nonvolatile compound in Chinese distilled spirits. J. Food Sci. 79, C1907-C1915. doi: 10.1111/1750-3841. 12650

Conflict of Interest Statement: The authors declare that the research was conducted in the absence of any commercial or financial relationships that could be construed as a potential conflict of interest.

Copyright (c) 2016 Joshi, Al-Wahaibi, Al-Bahry, Elshafie, Al-Bemani, Al-Bahri and Al-Mandhari. This is an open-access article distributed under the terms of the Creative Commons Attribution License (CC BY). The use, distribution or reproduction in other forums is permitted, provided the original author(s) or licensor are credited and that the original publication in this journal is cited, in accordance with accepted academic practice. No use, distribution or reproduction is permitted which does not comply with these terms. 